Jarosław Babka, Ph.D.

Faculty of Education, Sociology and Health Sciences

University of Zielona Góra

\title{
ROLE OF TASKS IN DEVELOPING COOPERATIVE BEHAVIOUR IN DISABLED AND FIT STUDENTS
}

\section{Introduction}

The problem of cooperation and cooperative behaviour of school students has rather been neglected by the Polish education both in theory and in practice. Western researchers have provided evidence for the benefits of cooperation which favours cognitive and social development of young people. The experiments carried out by, among others, Morton Deutsch (2005, p. 21-40), Eliot Aronson (2001, p. 324-334) showed, that people experiencing cooperation and interdependence more frequently communicated with one another, participated in discussions, liked one another more, were less aggressive, and the group in which they worked together grew more coherent. The researchers also pointed out that tasks were performed better by pupils who cooperated than by those who worked in competitive situations (Johnson, Johnson, 1989, p. 167-177). Eliot Aronson (2001, p. 330333 ) used joint actions successfully for eliminating ethic and racial divisions and prejudices among pupils at school. This leads to the conclusion that cooperation should be perceived not only as an organizational form of pupils, but also as an activity which improves social relations and is beneficial for social integration. In school practice it is frequent that a teacher gives pupils the following instruction: "divide into groups and elaborate the topic". However, the problem is more complex. The teacher should be aware of the fact that the task he formulates should depend on cognitive and social results he wants to get from his/her pupils. In book references there is a gap concerning the issues of tasks and task groups that can motivate children and adolescents for taking up cooperative activities. Western researchers, including, for example, Richard Arends (1995), Eliot Aronson (2001), Frank Borsch (2010), Bruce Joyce, Emily Calhoun David Hopkins (1999) use the concept of the model of cooperative learning in order to define such methods as: the jigsaw, a team survey/ team research, the double appraisal, which are 
based on joint action. In his paper the author refers to the task typology that was elaborated by Ivan D.Steiner (1972). Tasks are a measure that stimulates pupils to seek cooperation. The author verified the task types according to the processes undergoing in a group and to the so called productivity in obtaining certain results. The task typology can also be used in terms of getting social effects and eliciting cooperative behaviour from pupils. The theory as well as the practice of integrated education lacks agreements on what tasks can favour social development of pupils and how to organize them in groups in order to reach this. Despite the fact that the idea of social integration has been implemented for over twenty years now, unfortunately, no attention has been put to how only the disabled cooperate and how the activities are performed in heterogeneous groups composed of disabled and fit pupils. This is the aspect within which the author analyzes tasks as a factor conditioning cooperation which can improve social relations between the disabled and the fit and contribute to social integration. The paper presents the selected results of experimental research in which the productivity of task types was verified according to I.D. Steiner in terms of eliciting cooperative behaviour from pupils ${ }^{1}$.

The research took also to account the relation between the quality of cooperation when carrying out a certain task type and the type of a group depending on its composition. The research work focused on the differences among the three groups: (1) homogenous - composed only of disabled pupils, (2) homogenous, in which both disabled and fit pupils cooperated and (3) mixed, composed of pupils with special educational requirements and their fit peers.

\section{Tasks as a Measure Stimulating Pupils to Seek Cooperative Behaviour}

Task is a problem that occupies a special area in the science of education. It is difficult to imagine children's and adolescents' education without task performance. Several interesting concepts of tasks have been elaborated within the area of education and possibilities of their application have been indicated (compare Gnitecki, 1996; Jakowicka, 1987; Nowak-Łojewska, 2004; Waloszek, 1995). Tasks are approached as: (1) a regulator of human behaviour, (2) a didactic measure, (3) a system of structural features. The task concept is based on the output of psychology which provides conceptual apparatus and explanatory theories. According to Tadeusz Tomaszewski $(1979$, p. 504), "If in a certain situation a man sets a goal to achieve and a program to make it, we can say that he assigns a task to himself, whereas the situation which is supposed to be changed, is called a task situation".

${ }^{1}$ The set of all research results is the subject of the article entitled: "Cooperative Behaviour of Disabled and Fit Adolescents under Task Situations". 
Janusz Reykowski (1979, p. 789) thinks, that one can talk about a task only when a man has noticed a difference between the normal state (or desired) and the real state, has created the image of the conditions eliminating this difference (goal image) and has formulated his action programme. This results in finding out that the task is correlated with perceiving the difference between the desired and the real state as well as with anticipating the action programme being a condition for achievement of the goal and obtaining a result (Tomaszewski, 1979, p. 504). This task triad: goal-programme- result is expressed in educational approaches to task structure. It is worth stressing, that between the actual state and the expected image there is a course of situations related to making decisions by an individual on how to behave (Hajnicz, 19995, p. 78). Detecting a task which becomes a frame of reference for a man, as well as the path leading to its performance is a regulation process. Owing to the fact that a man assumes a task consciously and possesses the ability of self-regulation, that means of internal as well as external balance in a changing environment, his behaviour can be analyzed in terms of subjectivity, especially self-consciousness, agency and responsibility (Tomaszewski, 1984, p.132). According to Maria Tyszkowa (1990, p. 39) an individual can set tasks or the tasks can be imposed on him/her by others. The present analysis contributes to the approach in which tasks are perceived as a didactic measure that stimulates cooperative behaviour in pupils. The common feature of educational concepts of tasks is that they are viewed in terms of having an intentional effect on a pupil, who by performing certain activities acquires experience in favour of learning and obtaining various skills. The theory in which tasks are approached as a didactic measure allows to classify them into a group of task methods according to Krzysztof Konarzewski (1987). The author claims that the task method means to generate pupils' own activity by giving them tasks in order to make changes in their knowledge, skills and attitudes (Konarzewski, 1987, p. 175). Task is the basic element of educational-didactic process. According to Jan Poplucz (1984, p. 19) task is a logic fragment of goals and contents, which is available to be elaborated by pupils independently. A task should be clear, concrete and detailed, so that a pupil knows what he should do and in what way. The existing task analysis output gives two search trends. One trend refers to a broader task perspective. It is related to taking into account a subjective and situational aspect of the activities performed by a pupil and a teacher (Hajnicz, 1995; Grochulska, 1982; Łukaszewicz, 1992; Zwiernik, 1996). The other trend refers to the search for task types and their structural features in favour of activating, supporting development as well as integrating areas of children's personality. The knowledge of structural features enables conscious formulation of tasks due to the contents being the object of activity, mental operations involved in the task performance process as well as ways (methods) of making operations (Gnitecki,1996, p. 22-23; Jakowicka, 1987, p. 15; Nowak-Łojewska, 2004, p. 25-33; Waloszek, 1993, p.15-21).The abovementioned two study trends refer only to the task concepts, which were created by 
a need of search for alternative ways of children's education. Task concepts have many virtues to be used on various levels of education. Unfortunately, in the task theory nothing is said on using them as a measure that may foster development of children's social competence or the ability to work in teams. The majority of the studies referred to herein takes into account a form of performing tasks by pupils individually as well as using them mainly for developing mental sphere of pupils. The analyses neglected the importance that performing tasks in pairs, triads and teams has for social development of children and adolescents, especially in integrated classes. There is scientific evidence on the fact that performing tasks by pupils in cooperation with their peers fosters cognitive and social development (Musatii, 1995, p. 107-146; Rzechowska, 2004, p.371-376; Deutsch, 2005, p.2140; Aronson, 2001, p.324-334; Brown, 2006, p.46-470; Joyce, Calhoun, Hopkins, 1999 , p.98-114). Challenges resulting from social integration generate the need to apply tasks for stimulating pupils to seek cooperative behaviour. Ivan D.Steiner (1972) is the author of the typology, that is supposed to fill in the gap concerning tasks favouring cooperation among children and adolescents. The I.D.Steiner's approach is a significant concept in social psychology, which so far has not found its application in the Polish education. The concept has been verified in psychological tests that aimed at finding out whether in a particular task situation more productive is a group or an individual. I. Steiner noticed three groups of factors which condition group productivity: task type, team resources as well as the processes that are on in a group (Steiner, 1972; Brown, 2006, p.160). There is evidence that one of the factors that affects performance quality and the results obtained is a task type. I. Steiner mentions the following task types: summable-additive, divisible-disjunctive, unitary-conjunctive, compensatory and discretionary-divisible (compare Steiner, 1972, p. 14-39) (see. Table 1).

Table 1. Types of tasks in favour of cooperation

\begin{tabular}{|c|l|}
\hline Task type & \multicolumn{1}{c|}{ Definition } \\
\hline Additive & $\begin{array}{l}\text { It means that members of a particular group when performing the same tasks } \\
\text { obtain results better than those when acting individually. It is important that } \\
\text { individual performances of all the participants are summed up. }\end{array}$ \\
\hline Conjunctive & $\begin{array}{l}\text { Requires involvement of all group members, both the most and the least } \\
\text { competent. }\end{array}$ \\
\hline Disjunctive & $\begin{array}{l}\text { In this task type a group member identifies a correct solution of the problem } \\
\text { in the quickest time. }\end{array}$ \\
\hline Compensatory & $\begin{array}{l}\text { It means a discussion in which group members exchange individual solutions } \\
\text { in order to reach a mutual agreement. }\end{array}$ \\
\hline Divisible & $\begin{array}{l}\text { It means to divide a task into smaller elements, the so called sub-tasks to be } \\
\text { assigned to group members. }\end{array}$ \\
\hline
\end{tabular}

Source: Based on (Steiner, 1972, p. 14-39) 
The task types suggested by I. Steiner were verified with regard to the criterion of group performance potential productivity. In principle, all tasks help people find out that group performance is more productive than individual performance, provided it is well organized. Task productivity can only be analyzed in a potential aspect. It means that the actual potentiality, due to some interferences, may differ significantly from the assumed one, that is potential. It should be stressed that all the above-mentioned tasks require cooperative attitude from group members. During task performance pupils' cooperation will take different forms depending on the way the pupils are doing their job, work allotment and contribution or how the group members communicate with one another, because, as I.D. Steiner notices, each task has a different nature (Steiner, 1972, p.273). Here, the author finds another criterion for task analysis with regard to productivity ${ }^{2}$. It does not refer to a performance result (quantity, quality), the aspect earlier analyzed by researchers but to social framework that tasks impose on their performers for potential cooperation. As far as potential ${ }^{3}$ productivity of tasks with regard to interaction is concerned, the author perceives it as a social framework, interpersonal space that is made when working in a group that fosters pupils communication, contributes to making agreements on a strategy of actions and sharing knowledge, etc. In educational practice the level of pupils' cooperation can be defined by analyzing their interaction under task situations with the use of adequate criteria. This level can also be graded, for example high, average, low ${ }^{4}$. The analyses show that the author is interested more in the process of task performance itself, how pupils contribute to work and how it proceeds. The outcome (product) of pupils' performance is important, because it speaks for the group's effectiveness 5 , however it is not the only determinant of the performance evaluation. Processual approach finds a special application in education, which should teach children and adolescents to organize cooperation as well as to generate synergy which on long term contributes to increasing effectiveness and productivity of performance.

From educational point of view it would be advisable to analyze the task types (task nature) in terms of potential level of cooperation. This may lead to a conclusion that the widest range of interpersonal space, and thus the level of cooperation,

${ }^{2}$ The idea of productivity is approached differently depending on the area of knowledge, which hinders its use for education. Linguistically, "productive: means :producing much, giving good results, efficient, prolific, useful (Sobol, 1997,p.707). The author of the present paper links productivity with efficiency, good results depending on a certain criterion (cooperation), which pupils get when performing tasks.

${ }^{3}$ The author understands "potentiality" as "the existing set of circumstances, which assumes a latent ability; expecting that some currently unrevealed properties or talents will develop" (Reber, p.529).

${ }^{4}$ According to C. Oyster (2002, p. 359) the level of cooperation means the group property, which may facilitate or hinder the accomplishment of goals.

${ }^{5}$ Effectiveness is related to obtaining the expected result (Kotarbiński, 1999, p. 357). 
is offered to a similar degree by conjunctive, compensatory and summable tasks. Conjunctive tasks are in favour of negotiation and reaching agreements jointly, which provides real chances for occurrence of a wide communication spectrum and decentration of task performers. Compensatory tasks allow pupils to spot differences among one another as well as to find out that each pupil can be active and contribute to the job assigned provided its weaknesses and strengths have been taken into account. These task types are very valuable from educational point of view. In each school class there are both talented as well as less competitive pupils. These types of tasks contribute to strengthening relationship among the group members, favour protectiveness and elicit pro-community attitude. It is assumed, that tasks create chances for generating a very high level of interaction in pupils, provided they are well aware of their capabilities. A summable task is also related to a high level of cooperation, because it requires from its performers agreement on a strategy as well as a good coordination of efforts and communication. It may be exemplified by screams given by participants of joint actions that play a coordinative function or express pupils' reaction to the task completion, which definitely speaks for the group unity. Divisible tasks require from a group members to decide on the rules of cooperation, division of labor and the rules of assigning sub-tasks to be carried out. Owing to the fact that when performing this type of a task there is a stage of individual work, it is assumed, that these tasks are related to a lower level of cooperation. Moreover, a divisible task requires from its performers experience in dealing with complex tasks. As a result it may present certain cooperative problems and cause that intensity of expressing cooperative attitudes will be low. The lowest level of cooperation is related to a disjunctive task. In this type of tasks it is important that a group, through one of its members, identifies a solution in a short period of time, for example in a guessing game or charades. Tasks of this type are very often used in situations entailing competition among groups, which corresponds to a specific form of interaction, namely a negative cooperation. It should be stressed that the analysis of the selected task types is of a theoretical nature in terms of the cooperation level. Although psychology gives reasons for conditions of cooperative behaviour, it cannot be predicted, how an individual-a group will react in a particular task situation. It is important how a pupil perceives a situation and what meaning gives to it. It leads to a conclusion that in case of the tasks under analysis we can only study a potential level of cooperation. The relation between a task type and the actual level of cooperation requires researching.

\section{Methodology of Author's Own Research Work}

The research differed from the classical model of pedagogical experiment, which means introducing an experimental factor into a group of pupils and some time after it had acted taking measures and comparing them. A small number of 
disabled pupils in integrated classes (from 3 to 5 pupils included mentally handicapped) made it impossible to carry out the experiment under natural conditions, namely during lessons of integrated classes. The randomized experiment was then applied, which meant a random choice of classes comprising pupils participating in the research programme (Brzeziński, 2000, 2008, p.48-50). The tests were carried out in schools with integrated classes in the central-western region of Poland. The research covered 128 disabled pupils at the age of 14-15 within the intellectual standard and 128 non-disabled pupils. 256 junior high school students were subject to the tests. Pupils of junior high schools were chosen for the tests because adolescent students tend to function in smaller groups. Apart from that, analyzing junior high school students it is possible to determine the degree of development of their cooperative skills after they have completed the stage of kindergarten and school education which cannot be neglected in the process of developing social competence of an individual. The tests covered chronically ill pupils, physically handicapped, poorly hearing and with specific difficulties in learning. The disabled and fit pupils from integrated classes were selected for the tests at random to the following types of four-people task groups: experimental-homogenous (64 disabled pupils), control- homogenous (64 fit pupils), experimental-mixed (64 disabled pupils and 64 fit pupils). It was important that teams were formed of pupils from the same class. Mixed task groups consisted of two disabled pupils and two fit ones. According to the bibliography, small 3-4 people groups are most effective. Too numerous teams experience, for example social idleness (Grzelak, 2000, p.133). A task group was put into an experimental situation, which required performing a task and cooperation. The experimenter instructed pupils orally. Apart from that the participants were provided with written instructions in order to learn better about the rules of performing the task. Every team, including every pupil, was watched only once under experimental conditions by two competent arbiters, who recorded verbal and non-verbal conduct on an observation sheet specially prepared for this test. The observation carried out by means of the observation sheet including 12 indicators made it possible to assess cooperative behaviour of pupils cooperating with one another according to the four degree scale with figures assigned. Owing to this it was possible, among other things, to determine an arithmetic average of cooperative behaviour for every pupil and for every of the three groups compared. Apart from this, the test also included recording pupils' behaviour in a task situation according to the assumptions of a photographic observation (Lobocki, 2000, p.45080). The discussion of the test results was supplemented with the opinion poll concerning the opinion of pupils on cooperation at school (Lobocki, 2000, p.258-260). In order to give an answer to the questions on the difference of cooperation among the groups compared and in order to search for differences inside the groups the advanced statistic techniques were applied. The results presented in this chapter allow to give answers to the following questions: 
- Which task type facilitates pupils' cooperation the most and which one the least? The problem is related to an attempt to define task productivity in terms of triggering cooperative behaviour for a) all the test, b) the task groups compared: homogeneous with the disabled, homogeneous with fit pupils and a mixed group (heterogeneous) comprising both the fit and the disabled c) as well as inside groups (the disabled from the homogeneous and mixed groups and the fit from the homogeneous and mixed groups)?

- Do particular task types: additive, conjunctive, compensatory and disjunctive differentiate the level of pupils' cooperative behaviour?

The hypothesis that conjunctive, additive and compensatory tasks differentiate the level of cooperative behaviour in the three test groups. Disjunctive tasks are the least productive in terms of pupils' cooperative behaviour of all the other the other tasks types. There is a statistically significant difference between the cooperative arithmetic average obtained for the disjunctive task and the results obtained for all the other tasks. The experimenters withdrew from verifying the cooperation productivity of the disjunctive task Such tasks require from test participants to search for an answer without a mutual agreement. It is important that in a group there is a person that knows the answer.

\section{Task and a task group as a factor differentiating pupils' cooperation}

In view of the research carried out it was important to check productivity of particular tasks with regard to eliciting cooperative attitudes from pupils in the three groups compared. Basing on the observation of junior high school pupils under task situations and using a specially drawn up questionnaire, which enabled evaluation of twelve cooperative reactions shown by pupils in particular task types, the arithmetic mean of the level of cooperation was calculated. This procedure provided the averaged results for the three groups compared (homogenous - the disabled, homogenous - the fit, mixed - the disabled and the fit). It this paper the author approached cooperation as a higher level of interaction, which means involvement of several people (not fewer than two) in accomplishment of the mutual goal. The actual level of pupils' cooperation was evaluated by considering the cooperative behaviour which referred to: (1) features of activity/ involvement and (2) the results obtained. In the first criterion it was important to define to what degree the task performers see the common goal, express their will to act jointly, undertake a role of a leader, but do not dominate, talk about the task, are interested in the task completion and are stimulated cognitively and help one another. The second criterion is related to the analysis of the joint action effectiveness, which made it possible, apart from accomplishing the goal set, to obtain a synergy effect ${ }^{6}$. The following reactions

\footnotetext{
${ }^{6}$ Synergy means "an outcome of a team work, the product of which exceeds not only each of the inputs made, but even the sum of them all. In synergy two plus two is five, seven, nine, etc." See
} 
were notable here: being happy with performing the task together with other group members, sharing experience and knowledge while performing the task, expressing joy, showing confidence and acceptance towards other group members (Bąbka, 2007, p. 40-43). The author of the paper presents the averaged results of the analysis. Owing to this, it is possible to find in the collected empirical material a more general tendency. It does not mean though, that, for example, in an additive task or another, which moderately contribute to cooperation, there was not a group that got a result showing a high level of cooperation. The results shown should be interpreted so that the lower mean of cooperative behaviour for a particular task type and group, the slightly worse results of cooperation obtained by task performers. Three categories and the corresponding arithmetic mean ranges were assumed for defining the cooperation level: low 0-18 points, average 19-27 points, high 28-36 points.

The paper assumes that it is important to determine productivity of particular tasks regardless of the group type, that means with regard to the whole research test. The results show (compare table 2 and figure 1) that the highest scores concerning cooperation were obtained by pupils in the conjunctive task. Slightly worse results were in the additive and compensatory task. It should be stressed, that in all task types the arithmetic mean of the scores obtained by pupils correspond to an average level. In terms of cooperation level, the disjunctive task proved to be the least productive. In case of this task type, participants showed a low level of cooperative behaviour.

Table 2. The level of pupils' cooperative behaviour in three groups compared when performing the the additive, conjunctive, compensatory and divisible task

\begin{tabular}{|c|l|l|c|c|}
\hline \multirow{2}{*}{ Group type } & \multicolumn{1}{|c|}{ Task type } & \multicolumn{1}{c|}{$\begin{array}{c}\text { Cooperation } \\
\text { arithmetic mean }\end{array}$} & $\begin{array}{c}\text { Level of } \\
\text { cooperative } \\
\text { behaviour }\end{array}$ & $\begin{array}{c}\text { Number of test } \\
\text { participants }\end{array}$ \\
\hline \multirow{2}{*}{1} & \multicolumn{1}{|c|}{2} & 3 & 4 & 5 \\
\hline \multirow{4}{*}{$\begin{array}{l}\text { Experimental } \\
\text { (homogenous-the } \\
\text { disabled) }\end{array}$} & Additive & 19,7500 & Average & 16 \\
\cline { 2 - 6 } & Conjunctive & 26,6250 & Low & 16 \\
\cline { 2 - 6 } & Compensatory & 22,6250 & Average & 16 \\
\cline { 2 - 6 } & Divisible & 12,4375 & Low & 16 \\
\cline { 2 - 6 } & Total & 20,3594 & Average & 64 \\
\hline \multirow{3}{*}{$\begin{array}{l}\text { Experimental } \\
\text { (homogenous-the } \\
\text { disabled) }\end{array}$} & Additive & 28,3125 & Average & 16 \\
\cline { 2 - 6 } & Conjunctive & 27,9167 & Average & 16 \\
\cline { 2 - 6 } & Compensatory & 25,0500 & Average & 16 \\
\cline { 2 - 6 } & Divisible & 21,8125 & Average y & 64 \\
\cline { 2 - 6 } & Total & 25,5938 & & \\
\hline
\end{tabular}

D.Elsner, K.Kafel (1999, p. 139). The synergy related phenomena are, for example: feeling community, joy, etc. 
Table 2. (cd.)

\begin{tabular}{|l|l|l|c|c|}
\hline \multicolumn{1}{|c|}{1} & \multicolumn{2}{|c|}{3} & 4 & 5 \\
\hline \multirow{4}{*}{$\begin{array}{l}\text { Experimental } \\
\text { (mixed the } \\
\text { disabled and the } \\
\text { fit) }\end{array}$} & Additive & 23,3438 & Average & 64 \\
\cline { 2 - 6 } & Conjunctive & 22,1250 & Average & 64 \\
\cline { 2 - 5 } & Compensatory & 23,4687 & Average & 64 \\
\cline { 2 - 6 } & Divisible & 15,1563 & Low & 64 \\
\cline { 2 - 6 } & Total & 21,0234 & Average & 128 \\
\hline \multirow{4}{*}{ Total } & Additive & 23,6875 & Average & 64 \\
\cline { 2 - 6 } & Conjunctive & 24,4833 & Average & 64 \\
\cline { 2 - 6 } & Compensatory & 23,7353 & Average & 64 \\
\cline { 2 - 6 } & Divisible & 16,1406 & Low & 64 \\
\cline { 2 - 6 } & Total & 22,0000 & Average & 256 \\
\hline
\end{tabular}

Source: Author's own research

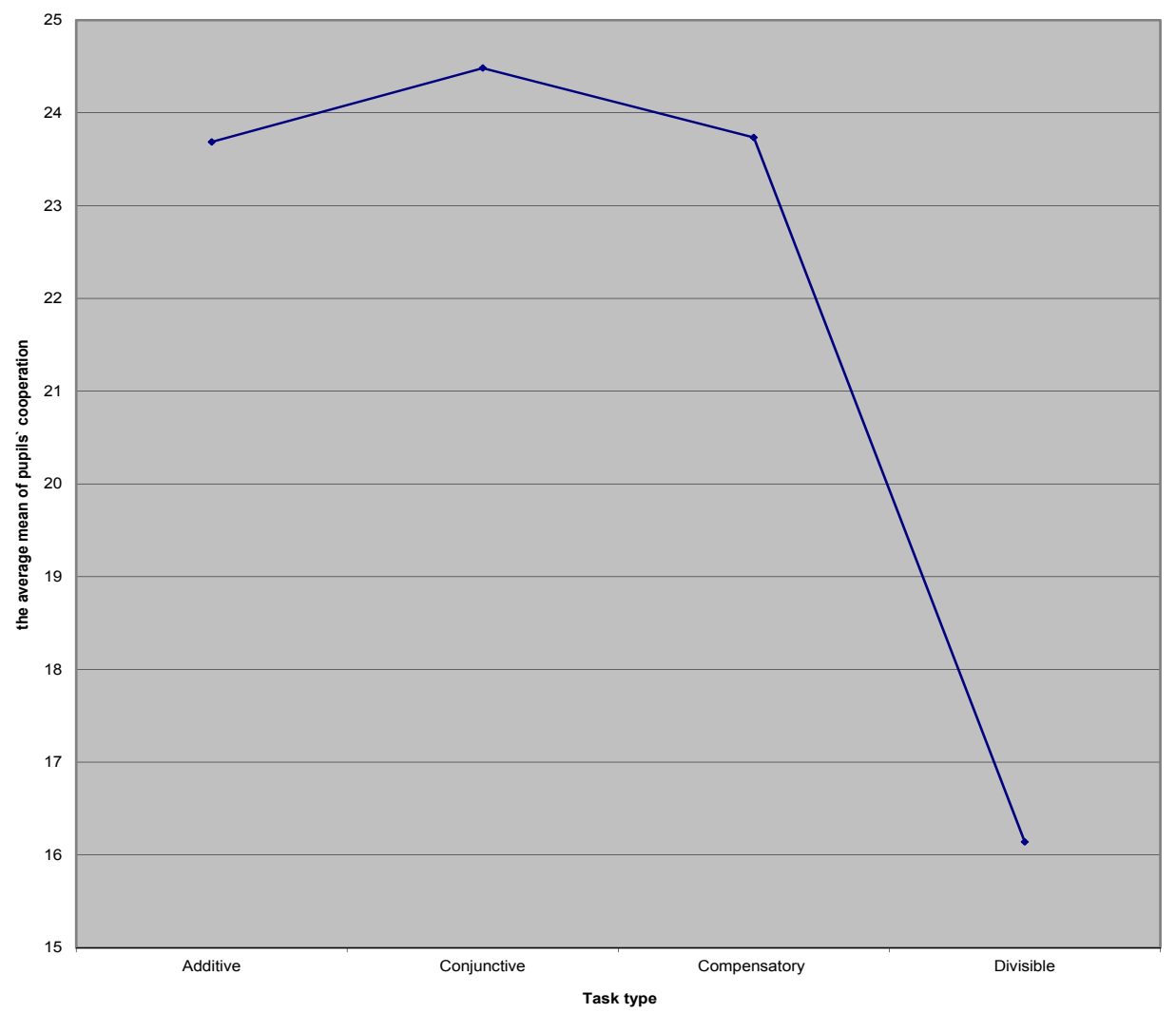

Figure 1. Level of cooperative behaviour of all the pupils participating in the additive, conjunctive, compensatory and divisible task 
Statistic analysis by means of inter-object effect tests showed that the selected independent variables, that is the group type $(\mathrm{F}=6,492 ; \mathrm{df}=2 ; 244 ; \mathrm{P}=0,002)$ and the task type $(\mathrm{F}=10,130 ; \mathrm{df}=3 ; 244 ; \mathrm{P}=0,000)$, as the analyzed basic determinants, differentiate the dependent measure, that is cooperative behaviour of pupils. However, there is no interaction among the determinants ${ }^{7}$. Owing to this, it is advisable to analyze the results concerning cooperation that pupils obtained in particular task types within the three task groups compared.

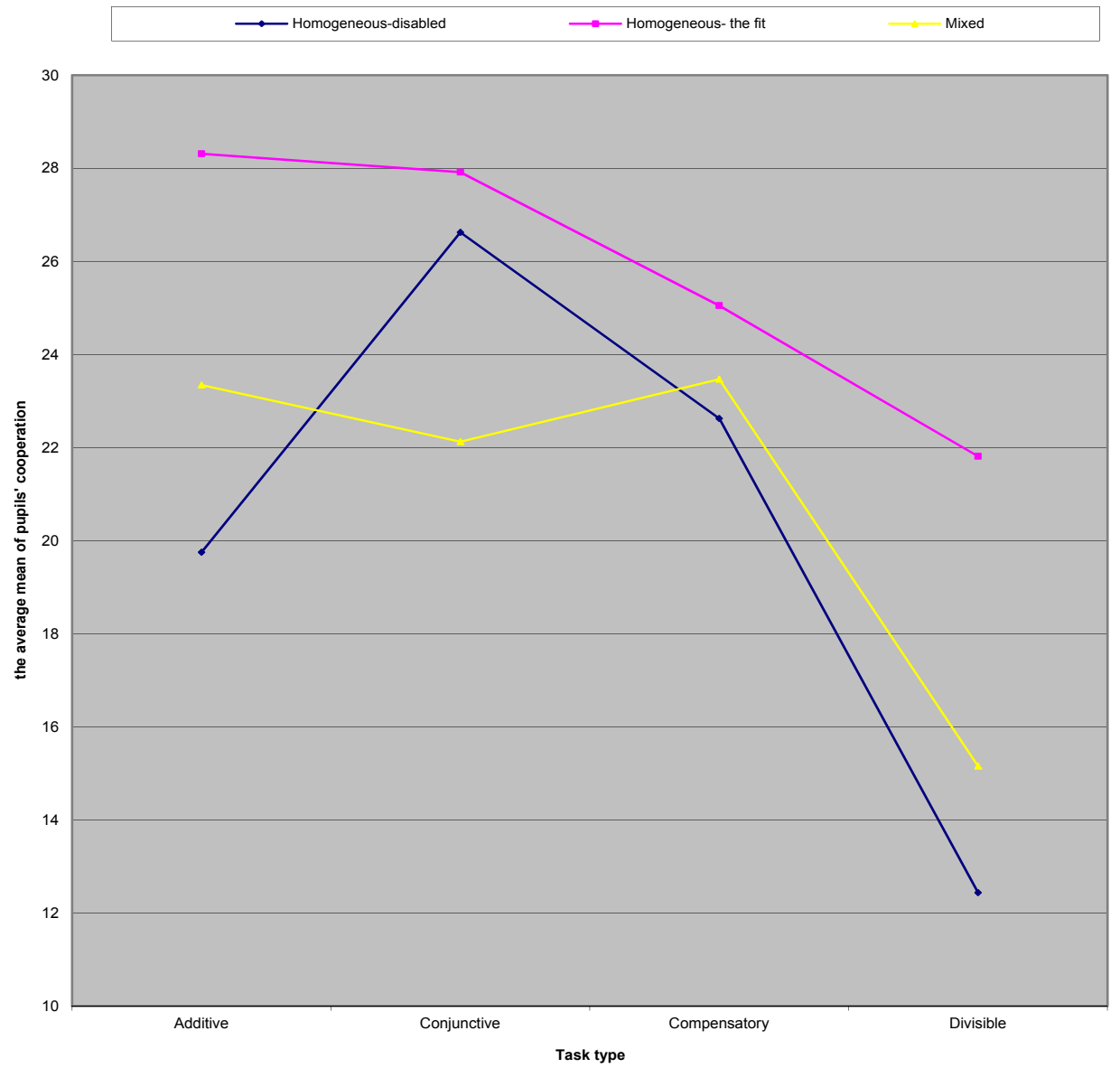

Figure 2. The level of pupils' cooperative behaviour in the additive, conjunctive, compensatory and divisible task presented by the subjects in three task groups

Source: Author's own research

${ }^{7}$ The applied ANOVA model allowed a two-determinant analysis of the variability of the sums of cooperative behaviour. 
The analysis shows (fig. 2) that a homogenous group of fit pupils (control) in all the task types got better results of cooperation in comparison with an experimental group composed of only disabled pupils and the experimental mixed group composed of both disabled and fit junior high school students. On the other hand, the mixed group (the second, experimental one) got better results in terms of cooperation than the homogenous one (the first, experimental one) in the three task types excluding the conjunctive task. It is worth analyzing why the conjunctive task was performed better by disabled pupils from a homogenous group than by their counterparts from the mixed group in which they cooperated with fit colleagues. The advantage of conjunctive tasks is the possibility of adapting the group performance to the most and the least competent participants. The analysis of the observation evidence shows that the fit pupils participating in this task type adapted their capabilities to the capabilities of the disabled colleagues, took over initiative and often imposed their opinion on them. This resulted in assuming a withdrawing attitude by the disabled.

The tests show that it is impossible to define a single type of a task that would be most productive in terms of pupils' cooperation in three groups compared (figure 3). In the homogenous group composed of disabled pupils, the conjunctive task proved to be the most productive and in this task its performers reached the upper limit of the average level. In terms of productivity the next was the compensatory task and the additive task (the average level).

The disabled pupils obtained the lowest results in the divisible task (a low level of cooperation) (compare table 2 and figure 2). In a homogenous group the fit pupils obtained the best results in the additive task in which they showed a high level of cooperation. These pupils obtained slightly worse results in the conjunctive task ( the upper limit of the average level) and then in the compensatory task ( the average level of cooperation). Similarly to the results of the disabled pupils, the divisible task proved to be the least productive. In case of this task, the mean result shows the average level of cooperation (compare table 2 and figure 2). In the mixed group, the best results, although only within the average level of cooperation, were obtained in the additive and compensatory task. The disabled and fit pupils from mixed groups obtained comparable results in the conjunctive task, whereas the divisible task proved to be the least productive in terms of pupils' cooperation (a low level of cooperation) (compare table 2 and figure 3). Thus, it is not possible to indicate one task type, that would be universal in terms of fostering cooperation with reference to the two experimental and one control group. The task groups compared obtained the best results as far as cooperation is concerned in various task types. It may be ascertained though, that the divisible task contributed the least to eliciting cooperative attitudes from pupils both in the experimental as well as in the control group. The arithmetic mean reached by the pupils in all groups while performing the divisible task corresponds to the low level of cooperative behaviour. 


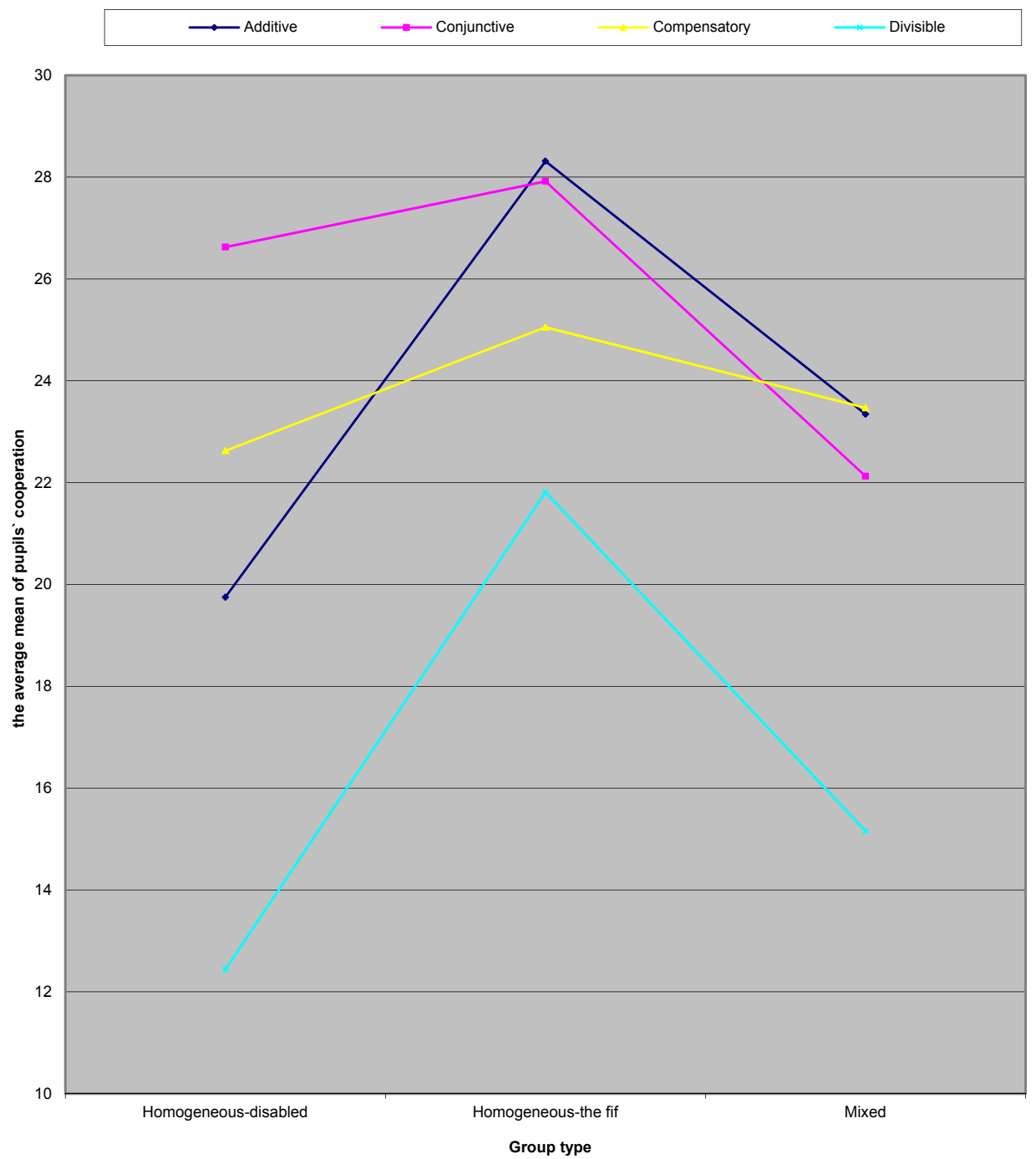

Figure 3. The level of cooperative behaviour of pupils from three groups in the additive, conjunctive, compensatory and divisible task

Source: Author's own research

For the researcher it was important to find the differences in the results concerning interaction while performing the four task types by pupils in the groups compared. It was crucial to determine whether there are differences in interaction between the disabled pupils performing tasks in homogeneous groups and the disabled performing the same tasks in the mixed groups with their fit classmates. Similar comparative analysis was applied to the fit pupils who were members of 
homogenous and mixed groups. It is visible (figure 4) that in case of the disabled the additive task contributed slightly more to cooperation in the mixed groups than in homogenous ones. In the conjunctive task the tendency was contrary. The compensatory tasks were slightly more in favour of cooperation in mixed groups. Although in the divisible task the subjects obtained poor results, the results were better in mixed groups than in homogenous ones. On the other hand, in the group of fit pupils the following tendencies were spotted. The additive, conjunctive, compensatory as well as the divisible task favoured cooperation more in homogenous groups than in the mixed ones.

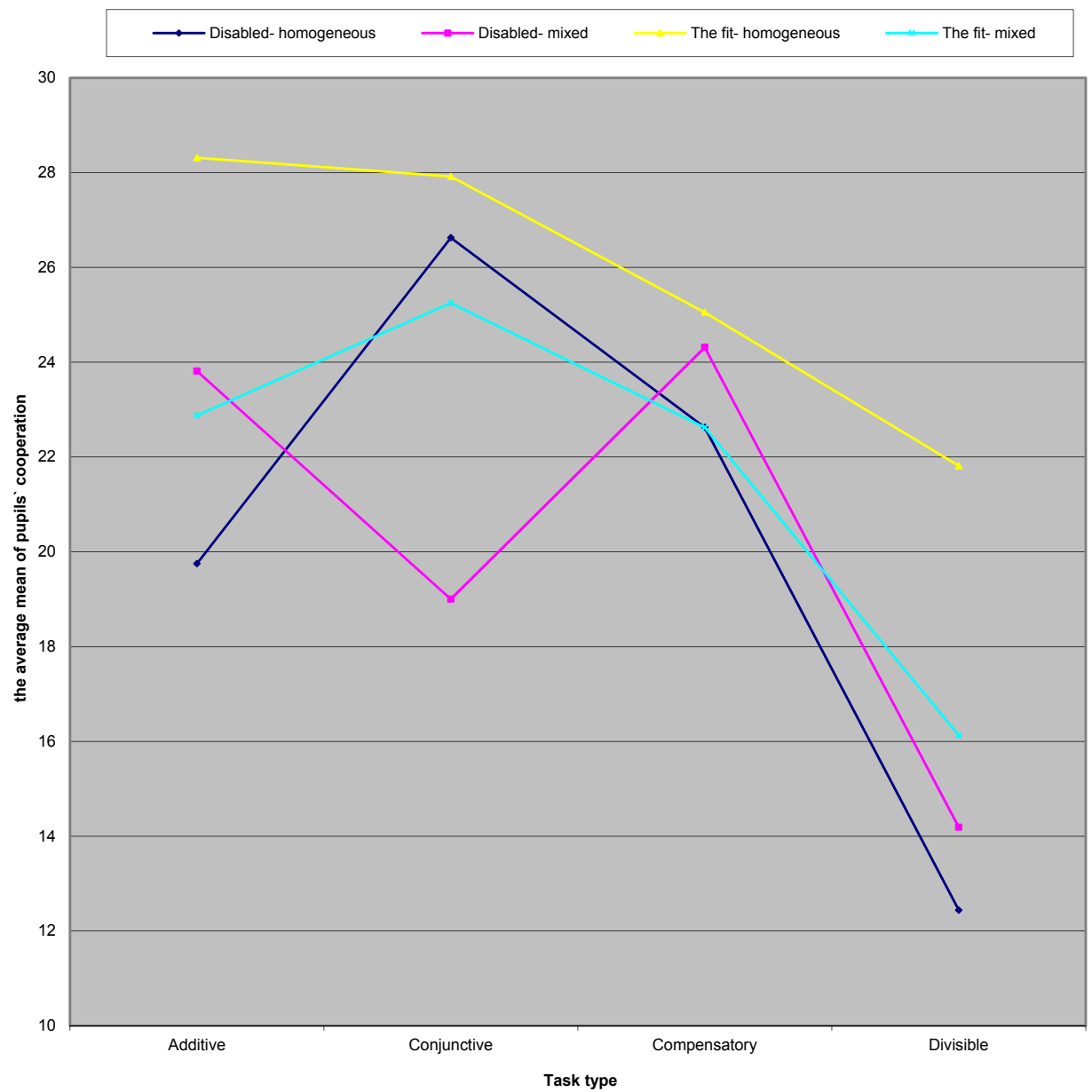

Figure 4. The level of pupils' cooperative behaviour in the additive, conjunctive, compensatory and divisible task presented by task performers within the groups compared

Source: Author's own research 
Several comparisons of the arithmetic mean for the tasks under analysis by means of the Bonferroni test showed that there is a statistically significant difference between the cooperation result obtained by pupils in the divisible task and the results concerning cooperative behaviour in the other tasks, namely the conjunctive, compensatory and additive. The level of cooperation in the divisible task was significantly lower than the level of cooperation manifested in other task types $(\mathrm{P}=0,000)$. In case of the other multiple comparisons the differences concerning cooperative attitudes shown while performing the tasks assigned were not statistically significant (table 3 ). The hypothesis that divisible tasks are the least productive in terms of cooperation was proved.

Table 3. Multiple comparison of tasks types basing on the difference between the arithmetic mean of the cooperation results

\begin{tabular}{|c|c|c|c|c|}
\hline (A) Task type & (B) Task type & $\begin{array}{c}\text { Difference in the } \\
\text { averages (A-B) }\end{array}$ & Standard error & Significance \\
\hline \multirow{4}{*}{ Additive } & Conjunctive &,- 7958 & 1,71016 & 1,000 \\
\cline { 2 - 5 } & Compensatory &,- 0478 & 1,65743 & 1,000 \\
\cline { 2 - 5 } & Divisible & 7,5469 & 1,68235 & $\mathbf{0 , 0 0 0}$ \\
\hline \multirow{4}{*}{ Conjunctive } & Sumowalne &, 7958 & 1,71016 & 1,000 \\
\cline { 2 - 5 } & Compensatory &, 7480 & 1,68565 & 1,000 \\
\cline { 2 - 5 } & Divisible & 8,3427 & 1,71016 & $\mathbf{0 , 0 0 0}$ \\
\hline \multirow{3}{*}{ Compensatory } & Additive &, 0478 & 1,65743 & 1,000 \\
\cline { 2 - 5 } & Conjunctive &,- 7480 & 1,68565 & 1,000 \\
\cline { 2 - 5 } & Divisible & 7,5947 & 1,65743 & $\mathbf{0 , 0 0 0}$ \\
\hline \multirow{3}{*}{ Divisible } & Additive & $-7,5469$ & 1,68235 & $\mathbf{0 , 0 0 0}$ \\
\cline { 2 - 5 } & Conjunctive & $-8,3427$ & 1,71016 & $\mathbf{0 , 0 0 0}$ \\
\cline { 2 - 5 } & Compensatory & $-7,5947$ & 1,65743 & $\mathbf{0 , 0 0 0}$ \\
\hline
\end{tabular}

Source: Author's own research

\section{Cooperative Behaviour of Disabled and Fit Pupils in Task Groups - Exemplification}

From a wide empirical material the author chose an exemplary description of pupils' activities while performing the divisible task in a mixed group - the disabled and the fit (the second experimental group). The author decided to choose this type of task, because it proved to be the least productive with regard to pupils' cooperation. The description and interpretation of the observation material aims to complement the above-presented statistical method. As it had been assumed, the divisible task required that its performers carried out sub-tasks and agreed on who 
would perform what things and how the activities of all the group members would be coordinated. All the task participants were offered the same task. The junior high school students were given the following instruction: 1. What interesting places to visit are there in the town (can they be historical buildings?) 2. Where can you do shopping and buy some trendy clothing? Where can you eat something tasty? What interesting places of entertainment are there in the town? Write about it to us on sheets of paper. Think, how can you do this task quickly. The best would be to assign tasks to one another in the group and decide who is going to write about what topic. Then, check if your answers are exhaustive enough? If not, how can you complement them?

In the divisible task "Town" there participated four junior high school pupils: Patryk - 15 years old (physically disabled), Karolina -15 years old (physically disabled), Mateusz - 15 years old (fit pupil) and Mateusz - 16 years old (fit pupil).

\section{Description of Pupils' Behaviour Under a Task Situation}

Table 4. Behaviour of Patryk, Karolina, Mateusz, Marek in the divisible task "Town"

\begin{tabular}{|c|c|c|c|}
\hline Patryk's behaviour & Karolina's behaviour & Mateusz's behaviour & Marek's behaviour \\
\hline $\begin{array}{l}\text { He is not interested in } \\
\text { the task. His assign- } \\
\text { ment was to describe } \\
\text { historical monuments, } \\
\text { the task nobody wanted } \\
\text { to do. } \\
\text { He wrote down some } \\
\text { examples of historical } \\
\text { monuments that can be } \\
\text { visited: the old town, } \\
\text { the town hall, the cita- } \\
\text { del. } \\
\text { He did not contact the } \\
\text { other group members. } \\
\text { He just sat indifferently } \\
\text { and waited for the oth- } \\
\text { ers to finish their tasks. } \\
\text { He exchanged notes } \\
\text { with his colleague, but } \\
\text { he did not add anything. }\end{array}$ & $\begin{array}{l}\text { She reads the instruc- } \\
\text { tions and says }-I \text { will } \\
\text { write where to do the } \\
\text { shopping. She was in- } \\
\text { terested in performing } \\
\text { the task. } \\
\text { She did not contact } \\
\text { anyone. } \\
\text { She exchanged her } \\
\text { notes with her col- } \\
\text { leagues, but she did not } \\
\text { add anything. } \\
\text { She was not happy with } \\
\text { the task. completion. }\end{array}$ & $\begin{array}{l}\text { He takes the instruction } \\
\text { out of the envelope and } \\
\text { reads it. } \\
\text { He holds the piece of } \\
\text { paper with his task } \\
\text { concerning the places } \\
\text { of entertainment in the } \\
\text { town. He works on his } \\
\text { task. He is preoccupied } \\
\text { with it. } \\
\text { He suggested to ex- } \\
\text { change the pieces of } \\
\text { paper to check the an- } \\
\text { swers. Let's exchange } \\
\text { our notes, we may add } \\
\text { something more. } \\
\text { He was not happy with } \\
\text { the task completion. } \\
\text { He exchanged the notes, } \\
\text { but he did not add any- } \\
\text { thing. }\end{array}$ & $\begin{array}{l}\text { After reading the instruc- } \\
\text { tion, he said: I will do the } \\
\text { fourth task. Where to eat } \\
\text { something good? } \\
\text { He thinks and writes } \\
\text { down the examples in } \\
\text { silence. } \\
\text { He exchanged the } \\
\text { notes, but he did not } \\
\text { add anything. } \\
\text { He was not happy with } \\
\text { the task completion. } \\
\text {. }\end{array}$ \\
\hline
\end{tabular}

Source: Author's own research 
All the members of this task group showed a low level of cooperative behaviour. After reading the instructions the pupils very quickly proceeded to choose the subtasks. This incogitant strategy was provoked by Marek, who just in the very beginning announced what he was going to write about. In this situation the group members acted following their own reasons concerning which subtasks to choose, because, for example "I know something about it", or "it seems to be the easiest task". The group lacked thinking in terms of "WE". Although they did complete the task, their cooperation was limited only to choosing sub-tasks, who was going to do what. They did not communicate with one another. Patryk, the disabled boy, seemed to be absent. Karolina, the disabled girl was involved in performing the task, however she was not aware of the fact that what she was doing was a part of a bigger whole. Mateusz, the fit boy showed the most cooperative attitude. In the beginning he handed the pieces of paper over to other group members. It was him to suggest interaction, which was to verify together the ideas put forward. Unfortunately, his suggestion did not trigger off exchanging ideas or adding new solutions. It should be stressed that pupils did not show that they were happy that they had completed the task. This speaks for the fact, that, although they worked on the same task, each of them had an impression that he/she was acting on their own.

\section{Conclusions}

The task typology by I.D. Steiner (1972) presented for the purpose of the research can find a special application in education as a measure for developing cooperation in pupils. The survey proves that for educational practice it is not unimportant what task a teacher can offer to his pupils and how he will form a group. It is important for pupils to acquire experience in performing all the task types distinguished, despite the fact that their productivity can be connected with the type of a task group (homogeneous, mixed).

The survey shows that, both the group type and the task type are determinants of the level of cooperation developed among the children. The survey, however, does not give grounds for distinguishing a single task type, which fostered cooperation among pupils in the three groups compared in the best way. The task groups compared obtained the best results for cooperation in various task types (although to a great extent it was an average cooperation level). The conjunctive task both in case of a homogenous group of fit pupils as well as a homogeneous group of disabled students can be characterized by a great productivity. On the other hand, the additive task favoured cooperation among the disabled, yet to a smaller degree in other groups. Attention should be focused on the tendency noticed that the divisible task, although it made it possible to obtain a certain result, proved to be the 
least productive as far as cooperative behavior of pupils both in homogeneous as well as in mixed groups is concerned.

The survey proved assumptions supported by the analysis of the reference books, that the divisible tasks develop pupils' cooperation in a smaller degree than in the conjunctive, additive and compensatory task. The level of pupils' cooperation in the divisible task was significantly lower than the level of cooperation in the other task types. In case of other multiple comparisons the differences were not statistically significant. It may lead to the conclusion that divisible tasks provoke individual work. Only on some other stage of linking the results from the sub-tasks performed and making one whole out of them the cooperation is possible. Unfortunately, in the groups under analysis, such a cooperation was not developed. It may be concluded that divisible tasks require from pupils advanced social competence and a wide experience in organizing joint action.

Composition of a task group differentiates the level of cooperation. The survey shows that both the group and the task type are determinants of the level of pupils' cooperation. The homogeneous group of fit pupils (control) obtained better results of cooperation in all the task types than the experimental mixed group composed of both the fit and the disabled. This means, that dividing groups depending on psychophysical fitness can cause difficulties in communication among pupils, hinder compliance with the rules that are conditions of joint action which leads to lowering the level of cooperation.

In the article the author follows the approach of such researchers as, for example, Richard Arends (2001), Robyn M.Gilles (2007) towards the values of heterogeneous groups in terms of pupils' acquiring certain knowledge and in terms of developing certain social skills. Cooperation developed in the mixed groups between the fit pupils and those with special educational needs. It needs a better insight whether this cooperation could be more efficient. According to the experts, including R.M. Gilles (2007, p. 29-34) cooperation is not a skill to be waited for until it appears with age. The author thinks, that during the educational process students should be provided with opportunities for experiencing interdependence through tasks, the performance of which is a sum of the activities of all the group members. Furthermore, the author adds, it requires exercises that could develop pupils' communication skills, empathy and the ability to assume the roles of other group members. The fit pupils interacted better in homogeneous groups than in mixed groups, yet the differences between the results obtained were not statistically significant. On the other hand, the differences between the cooperative results obtained by the disabled from a homogeneous and mixed group were especially strongly distinguished in conjunctive tasks (figure 4). It should be investigated why both the fit as well as the disabled obtained worse results in a mixed group than in the homogeneous one. The answer may be that the disabled pupils hindered effective cooperation in some way. The research material shows that the junior high school students with special needs ran into difficulties in cooperating 
with fit students in mixed groups in terms of their will to take up a joint action, little interest in acting together, suggesting solutions to a problem, and communicating with their peers. It cannot be neglected though that the fit pupils did not possess the adequate competence in favour of establishing interaction with the disabled colleagues and organizing cooperation. The observation of the fit junior high school students in the mixed groups showed that these pupils were not always willing to act jointly with the disabled, tended to be dominant over the others and to impose their point of view and frequently to replace their colleagues in order to finish the task as soon as possible. The fit pupils in mixed groups were not as much happy with the joint action as their colleagues in a homogeneous group of fit pupils. This is a result of the fact that the pupils under investigation need a joint action training and they should acquire experience in group behaviour. Fit students cannot stop, limit or replace the disabled, on the other hand the disabled cannot wait passively for the task completion without their involvement.

\section{References}

Arends R.I.V. (1995). Uczymy się nauczać, translated by K. Kruszewski. Warszawa: WSiP. Aronson E. (2001). Człowiek istota społeczna, translated by J. Radzicki. Warszawa: PWN.

Bąbka J.( 2007). Uczenie we wspótpracy - na przykładzie przedszkolnej grupy integracyjnej, [In:] A. Nowak-Łojewska, I. Kopaczyńska [Eds.]. Obszary wspólnego zaangażowania w edukacji dzieci. Zielona Góra: Oficyna Wydawnicza Uniwersytetu Zielonogórskiego, pp. 39-52;

Borsch F.(2010). Kooperatives Lehren und Lernen im schulischen Unterricht. Verlag W. Kohlhammer, Stuttgart.

Brown R. (2006). Procesy grupowe. Dynamika wewnątrzgrupowa i międzygrupowa, translated by J. Suchecki. Gdańsk: GWP.

Brzeziński J. (2008). Badania eksperymentalne $w$ psychologii $i$ pedagogice, Warszawa: Wydawnictwo Naukowe Scholar.

Deutsch M. (2005). Wspótpraca i rywalizacja [In:] M. Deutsch, P.T. Coleman [Eds.]. Rozwiąywanie konfliktów, p. 21-40, translated by M. Kodura. Kraków: Wydawnictwo Uniwersytetu Jagiellońskiego,

Elsner D. (1999). Jak organizować wewnątrzszkolne doskonalenie nauczycieli? Chorzów: Mentor.

Gillies R.M. (2007). Cooperative Learning. Integrating Theory and Practice. Los Angeles, London, New Delhi, Singapore: Sage Publikations.

Gnitecki J. (1996). Teoria zintegrowanych zadań szkolnych. Poznań: UAM.

Grochulska J. (1992). Wspomaganie rozwoju społecznego dziecka. Wrocław, Kraków: Zakład Narodowy im. Ossolińskich.

Grzelak J. (2000). Wspótzależność społeczna [In:] J. Strelau [Ed.]: Psychologia. Podręcznik akademicki, tom 3. GWP, Gdańsk, pp. 125-144;

Hajnicz W. (1995). Dwupodmiotowość i dwuzadaniowość sytuacji edukacyjnych w świetle ogólnej teorii regulacyjnej Tadeusza Tomaszewskiego. Olsztyn: WSP.

Johnson D.W., Johnson R.T. (1989). Cooperation and Competition: Theory and Research. Edina Minnesota: Interaction Book Company.

Joyce B., Calhoun E., Hopkins D. (1999). Przykłady modeli uczenia się i nauczania, translated by K. Kruszewski. Warszawa: WSiP. 
Kotarbiński T. (1999). Dzieła wszystkie. Prakseologia. Część I. Wrocław, Warszawa, Kraków: Zakład Narodowy im. Ossolińskich Wydawnictwo PAN.

Konarzewski K. (1987). Podstawy teorii oddziatywań wychowawczych. Warszawa: PWN.

Łobocki M. (2000). Metody badań pedagogicznych. Kraków: Oficyna Wydawnicza Impuls.

Łukaszewicz R. (1994). Edukacja z wyobraźnia, czyli jak podróżować bez map. Wrocław: Wydawnictwo Uniwersytetu Wrocławskiego.

Musatti T. (1995). Wczesne relacje rówieśnicze wedtug Piageta i Wygotskiego, translated by A. Kosnarewicz, [In:] A. Brzezińska, G. Lutomski, B. Smykowski [Eds.]: Dziecko wśród rówieśników i dorosłych, p. 107-146. Poznań: Wydawnictwo Zysk i S-ka.

Nowak-Łojewska A. (2004). Zintegrowane zadania w edukacji wczesnoszkolnej. Kraków: Oficyna Wydawnicza Impuls.

Oyster C.K. (2000). Grupy Psychologia społeczna, tłum.: A. Bezwińska-Walerjan. Poznań: Wydawnictwo Zysk i S-ka.

Poplucz J. (1984). Zadaniowa i czynnościowa organizacja lekcji. Kwartalnik Pedagogiczny, 4, p. 39-51;

Reber A.S. (2002). Stownik psychologii [Eds.] I. Kurcz, K. Skarżyńska. Warszawa: Wydawnictwo Naukowe Scholar.

Reykowski J. (1979). Osobowość jako centralny system regulacji i integracji czynności, p. 762-825. [In:] T. Tomaszewski [Ed.]. Psychologia. Warszawa: PWN.

Rzechowska E. (2004). Potencjalność w procesie rozwoju: mikroanaliza konstruowania wiedzy $w$ dziecięcych interakcjach rówieśniczych. Lublin: KUL.

Sobol E., [Ed.]. (1997). Mały słownik języka polskiego. Warszawa: PWN.

Steiner I.D. (1972). Group process and productivity. New York, London: Academic Press.

Tomaszewski T. (1979). Podstawowe formy organizacji i regulacji zachowania [In:] T. Tomaszewski [Ed.]. Psychologia, pp. 491-534. Warszawa: PWN.

Tomaszewski T. (1979). Człowiek $i$ otoczenie, [In:] T. Tomaszewski [Ed.]. Psychologia, pp. 13-36. Warszawa: PWN.

Tomaszewski T. (1884). Ślady i wzorce. Warszawa: WSiP.

Tyszkowa M. (1990). Aktywność i działalność dzieci i młodzieży. Warszawa: WSiP.

Waloszek D. (1993). Przygotowanie dzieci sześcioletnich do zadań szkolnych. Zielona Góra: WSP.

Zwiernik J. (1996). Alternatywa w edukacji przedszkolnej. Studium teoretyczno-empiryczne. Wrocław: Wydawnictwo Uniwersytetu Wrocławskiego. 